\title{
DUAL ACTION OF PANCURONIUM ON SUCCINYLCHOLINE BLOCK
}

\author{
Anthony D. Ivankovich, Naomi Sidell, Vincent J. Cairoli, Albert A. Dietz, \\ and Ronald F. Albrecht
}

CERTAIN ADVERSE EFFECTS of succinylcholine (SCh) such as increased intraabdominal pressure, muscle pain, hyperkalaemia and arrhythmias can be attenuated or eliminated by prior administration of a sub-paralyzing dose of non-depolarizing muscle relaxant. ${ }^{1-3}$ However, it has been shown that non-depolarizing muscle relaxants such as d-tubocurarine ( $\mathrm{dTC}$ ) and gallamine, antagonize a depolarizing type of neuromuscular block. ${ }^{4-6}$ Consequently, several investigators have recommended that when small doses of non-depolarizing muscle relaxants are given before $\mathrm{SCh}$, then larger doses of $\mathrm{SCh}$ should be given to achieve satisfactory relaxation..$^{7-8}$

Since pancuronium is a non-depolarizing muscle relaxant, it would be expected to affect SCh neuromuscular blockade in a similar manner. Several studies primarily concerned with the efficacy of sub-paralyzing doses of pancuronium to prevent $\mathrm{SCh}$ fasciculations without interfering with adequate relaxation have been reported ${ }^{8-10}$ Many of these studies have utilized single doses and/or did not report appropriate control data, making it difficult to evaluate the effects of pancuronium on the onset and duration of SCh-induced paralysis.

The purpose of this study was to evaluate quantitatively the effect of pretreatment with both sub-paralyzing and paralyzing doses of pancuronium compared with $\mathrm{dTC}$, on the onset and duration of neuromuscular blockade produced by $\mathrm{SCh}$, and to correlate these findings with changes in serum cholinesterase activity. Observations were also made to detect any adverse effects caused by the administration of a depolarizing muscle relaxant in the presence of non-depolarizing neuromuscular block.

\section{METHODS}

The effects of dTC and pancuronium on the onset and duration of SCh neuromuscular block and on serum cholinesterase activity were studied in 225 adult patients (ASA class I or II) during anaesthesia and surgery. The effect of pancuronium on three known variants of serum cholinesterase was also studied in vitro. Most of the patients were premedicated with a combination of atropine, hydroxyzine and meperidine. Two series of in vivo experiments and one in vitro series were performed.

Anthony D. Ivankovich, M.D., and Vincent J. Cairoli, Ph.D., Department of Anesthesiology, Illinois Masonic Medical Center, University of Illinois, Abraham Lincoln School of Medicine, Chicago, Illinois.

Naomi Sidell, M.D., and Ronald F. Albrecht, M.D., Department of Anesthesiology, Michael Reese Medical Center, Chicago, Illinois.

Albert A. Dietz, Ph.D., Biochemistry Laboratory, Veterans Administration Hospital, Hines, Illinois, U.S.A.

Canad. Anaesth. Soc. J., vol. 24, no. 2, March 1977 
TABLE I

Experimental Design for Part I

\begin{tabular}{ccll}
\hline \hline Group & $\begin{array}{c}\text { No. of } \\
\text { patients }\end{array}$ & \multicolumn{2}{c}{ Drugs administered } \\
\hline 1 & 15 & Control group & SCh., $1 \mathrm{mg} / \mathrm{kg}$ \\
2 & 15 & d-Tubocurarine, 5 $\mathrm{mg}$ & SCh., $1 \mathrm{mg} / \mathrm{kg}$ \\
3 & 15 & Pancuronium, 1.5 mg & SCh., $1 \mathrm{mg} / \mathrm{kg}$ \\
4 & 15 & Control group & SCh., 1.5 mg/kg \\
5 & 15 & d-Tubocurarine, $5 \mathrm{mg}$ & SCh., 1.5 mg $/ \mathrm{kg}$ \\
6 & 15 & Pancuronium, 1.5 mg & SCh., 1.5 mg/kg \\
7 & 15 & Control group & SCh., $2 \mathrm{mg} / \mathrm{kg}$ \\
8 & 15 & d-Tubocurarine, 5 mg & SCh., $2 \mathrm{mg} / \mathrm{kg}$ \\
9 & 15 & Pancuronium, 1.5 mg & SCh., 2 mg/kg \\
\hline
\end{tabular}

Part I: Effect of d-tubocurarine $5 \mathrm{mg}$ and pancuronium $1.5 \mathrm{mg}$ on the onset and duration of succinylcholine block

In the first part of the study we examined the effects of dTC $5 \mathrm{mg}$ and of pancuronium $1.5 \mathrm{mg}$ on the onset and duration of the neuromuscular blockade produced by three different doses of succinylcholine ( $1 \mathrm{mg}, 1.5 \mathrm{mg}$, and $2 \mathrm{mg} / \mathrm{kg}$ ). Nine groups of 15 patients each were studied according to the experimental design shown in Table I. The protocol was standardized in the following manner: a 16-gauge venous catheter was inserted in the forearm and Innovar $2 \mathrm{cc}$ was administered slowly. Pancuronium $1.5 \mathrm{mg}$ or dTC $5 \mathrm{mg}$ was given and three minutes later anaesthesia was induced with sodium thiopentone 3 to $5 \mathrm{mg} / \mathrm{kg}$. Ventilation was controlled using 50-60 per cent $\mathrm{N}_{2} \mathrm{O}$ in $\mathrm{O}_{2}$ by mask. An adductor pollicis twitch response was elicited by stimulating the ulnar nerve with supramaximal rectangular pulses $(0.3 \mathrm{msec}$ duration, $0.3 \mathrm{cps})$ at the ulnar grove, using a single block-aid monitor for all patients. Succinylcholine was injected rapidly into the open intravenous line and adduction of thumb or flexion of fingers was observed to be present or absent. The onset of the block was expressed in seconds from the time SCh was injected, until the total abolition of any visible twitch. The duration of the neuromuscular block was expressed in seconds from the injection of SCh until return of the first visible twitch.

In 15 patients venous blood was withdrawn prior to pretreatment with either dTC or pancuronium, again five minutes after their administration, and finally after SCh $2 \mathrm{mg} / \mathrm{kg}$, for the determination of cholinesterase (EC 3.1.1.8) activity. The method of Dietz, et al. ${ }^{11}$ was automated for the Bausch and Lomb "Spectronic System 400 ". Using the automatic dilutor, $20 \mu \mathrm{l}$ of serum were diluted with $1.98 \mathrm{ml}$ of DTNB [5,5'dithiobis-2-nitrobenzoic acid $125 \mathrm{mg}$ in 1 litre phosphate buffer, $\mathrm{pH} 7.6 \mu \pm 0.1]$. This mixture was maintained at $37^{\circ} \mathrm{C}$ for five minutes and $0.5 \mathrm{ml}$ PTCI propionylthiocholine iodide $(10 \mathrm{mM})$ was automatically added. The complete reaction mixture was transferred automatically to the spectrophotometer cell, the kinetic reaction monitored for 30 seconds and the activity printed out as $\mu \mathrm{mol}$ PTCI hydrolyzed $/ \mathrm{min} / \mathrm{ml}$. Dibucaine inhibition was measured by adding it to the substrate and the reaction continued as above, with inhibition calculated as the difference between the activities in the absence and presence of dibucaine. The concentrations of the ingredients in the final assay mixture were: PTCI 2, dibucaine 0.03, DTNB 0.254, and phosphate $25 \mathrm{~mol} /$ litre. A millimolar absorptivity 
TABLE II

Experimental Design for Part II

\begin{tabular}{|c|c|c|}
\hline Group & $\begin{array}{l}\text { No. of } \\
\text { patients }\end{array}$ & Drugs administered \\
\hline $\begin{array}{l}10 \\
11 \\
12 \\
13 \\
14 \\
15\end{array}$ & $\begin{array}{l}15 \\
15 \\
15 \\
15 \\
15 \\
15\end{array}$ & 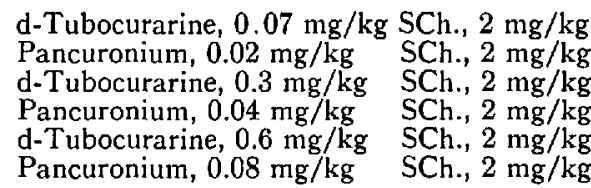 \\
\hline
\end{tabular}

of 13.6 for the reaction product, 5-thio-2-nitrobenzoate was used for the calibration setting of the computer.

Part II: Effect of different doses of d-tubocurarine and pancuronium on the onset and duration of succinylcholine

In part two of the study, the effects of three different doses of pancuronium $(0.02 \mathrm{mg} / \mathrm{kg}, 0.04 \mathrm{mg} / \mathrm{kg}$, and $0.08 \mathrm{mg} / \mathrm{kg})$ and of $\mathrm{dTC}(0.07 \mathrm{mg} / \mathrm{kg}, 0.3 \mathrm{mg} / \mathrm{kg}$, and $0.6 \mathrm{mg} / \mathrm{kg}$ ) on the neuromuscular blocking action of SCh, $2 \mathrm{mg} / \mathrm{kg}$ were studied. Each patient served as his own control in an experimental design illustrated in Table II. Following the administration of Innovar $2 \mathrm{cc}$ and thiopentone 3 to $5 \mathrm{mg} /$ $\mathrm{kg}$, SCh was administered rapidly and the ulnar nerve was stimulated with the Block-Aid monitor as in Part I of the study. In addition, the force of thumb adduction was measured using a Grass FT-10 force displacement transducer and HewlettPackard recorder. The time from $\mathrm{SCh}$ injection until the twitch was abolished and the time from $\mathrm{SCh}$ injection until the first twitch reappeared were measured. The trachea was intubated and 60 per cent nitrous oxide in $\mathrm{O}_{2}$ was added into the system. Following recovery of the twitch to control height, dTC or pancuronium was given. SCh administration was repeated when the twitch height had stabilized for 2 to 3 minutes at a level greater than 30 per cent of control, or in the case of larger doses of the non-depolarizing muscle relaxants, when it had recovered to 20 to 30 per cent of initial height. Intervals of 10 to 30 minutes between SCh injections have been reported to be adequate to avoid tachyphylaxis. ${ }^{6,7}$ The time from $\mathrm{SCh}$ injection until the twitch disappeared and the time from SCh injection until the first twitch reappeared were again determined. Some patients were tested at appropriate intervals with tetanic stimulation $(50-75 \mathrm{~Hz}, 5-10 \mathrm{sec})$, to determine the presence of a depolarizing or non-depolarizing type of neuromuscular block. ${ }^{12}$ The doses of non-depolarizing muscle relaxants were then repeated as needed for surgical relaxation. Reversal of the non-depolarizing neuromuscular block was done routinely at the termination of operation with an atropine-neostigmine mixture ( $1.0 \mathrm{mg}$ and $2.5 \mathrm{mg}$, respectively).

In 15 patients, venous blood was withdrawn before the administration of pancuronium $0.08 \mathrm{mg} / \mathrm{kg}$, as well as five minutes after its administration, and again at 40 minutes, just prior to a repetition of the SCh test dose for the estimation of pseudocholinesterase activity. The method was described in Part I.

The mean value for each factor under study was calculated. Results were analyzed for statistical significance by fixed analysis of variance within each experimental group. 
Part III: In vitro effect of pancuronium on serum cholinesterase

The in vitro inhibition by pancuronium bromide (Pavulon, Organon) of three known variants of serum cholinesterase was studied, by diluting the commercial solution $(2 \mathrm{mg} / \mathrm{ml})=0.273 \mathrm{mmol} / \mathrm{l})$ to give concentrations of 2 to $40 \times 10^{-7} \mathrm{~mol} / \mathrm{l}$. The percent inhibition of cholinesterase activity was measured using the method of Dietz ${ }^{11}$, described in Part I, except that the assay was done manually. The in vitro inhibition of cholinesterase by $\mathrm{dTC}$ could not be studied with PTCI as substrate, since dTC also reacted with DTNB in the absence of serum.

\section{Results}

Part I: Effect of d-tubocurarine $5 \mathrm{mg}$ and pancuronium $1.5 \mathrm{mg}$ on the onset and duration of succinylcholine block

The results for Part I of the study are summarized in Table III. The average time from the administration of $\mathrm{SCh} 1 \mathrm{mg} / \mathrm{kg}$, until the abolition of any visible twitch was 65.6 seconds, while the average time for return of the first visible twitch was 427 seconds. When the dose of SCh was increased to $1.5 \mathrm{or} 2 \mathrm{mg} / \mathrm{kg}$ there was, as expected, a progressive decrease in onset time and increase in duration of neuromuscular block; but a significant difference occurred only when the dose was doubled from $1 \mathrm{mg} / \mathrm{kg}$ to $2 \mathrm{mg} / \mathrm{kg}$. Pretreatment with either dTC $5 \mathrm{mg}$ or pancuronium $1.5 \mathrm{mg}$ significantly increased time to abolition of twitch for all doses of $\mathrm{SCh}$. As the SCh dose was increased this antagonistic effect was progressively decreased so that onset time to complete block after SCh $2 \mathrm{mg} / \mathrm{kg}$ was again equivalent to that after the $\mathrm{SCh} 1 \mathrm{mg} / \mathrm{kg}$ control dose given alone. The nondepolarizing muscle relaxants had opposite effects on the duration of the SCh block. Duration was decreased by dTC and increased by pancuronium at all three SCh dosages. The preceding data are shown in graphic form in Figures 1 and 2.

Following pancuronium $1.5 \mathrm{mg}$ several patients complained of weakness and inability to open their eyes, while two experienced breathing difficulties. Although $\mathrm{SCh}$ fasciculations were generally not observed in patients pretreated with $\mathrm{dTC}$ or pancuronium, they were not studied systematically in these experiments and no data is given.

\section{Effect of d-tubocurarine $5 \mathrm{mg}$ and pancuronium $1.5 \mathrm{mg}$ on serum cholinesterase activity}

Average values for serum cholinesterase activity in eight patients given dTC $5 \mathrm{mg}$ and in seven patients given pancuronium $1.5 \mathrm{mg}$ are shown in Table IV. These doses produced small insignificant decreases in serum cholinesterase activity compared with control levels. The effect of a subsequent injection of SCh $2 \mathrm{mg} / \mathrm{kg}$ was negligible. There was no correlation between the duration of SCh block after dTC or pancuronium and levels of serum cholinesterase activity.

Part II: Effects of different doses of d-tubocurarine and pancuronium on the onset and duration of succinylcholine block

A typical experiment is illustrated in Figure 3. The administration of SCh 2 $\mathrm{mg} / \mathrm{kg}$ produced a complete abolition of twitch response for six minutes with no post-tetanic facilitation during the recovery phase. Following full recovery of 


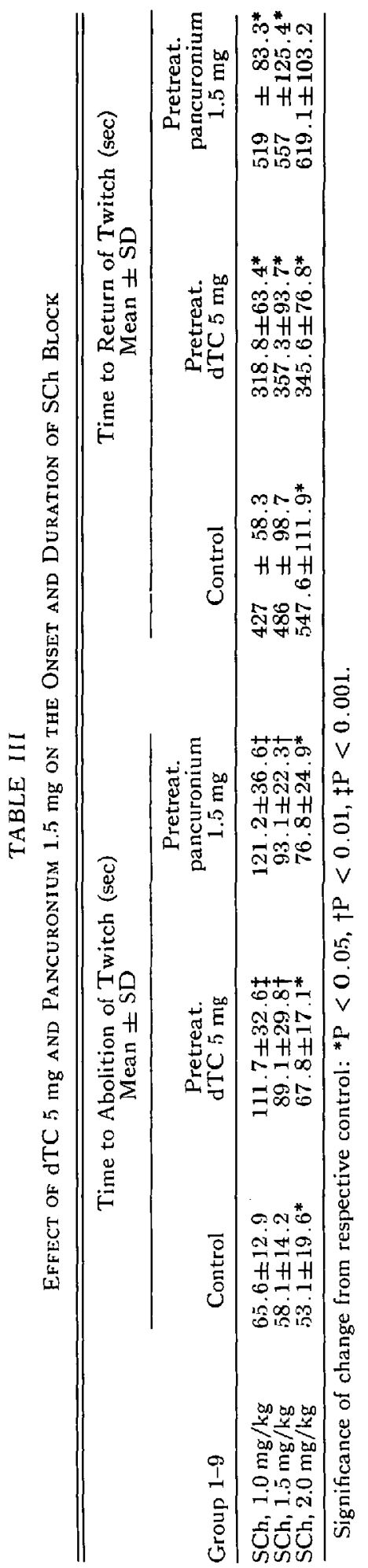




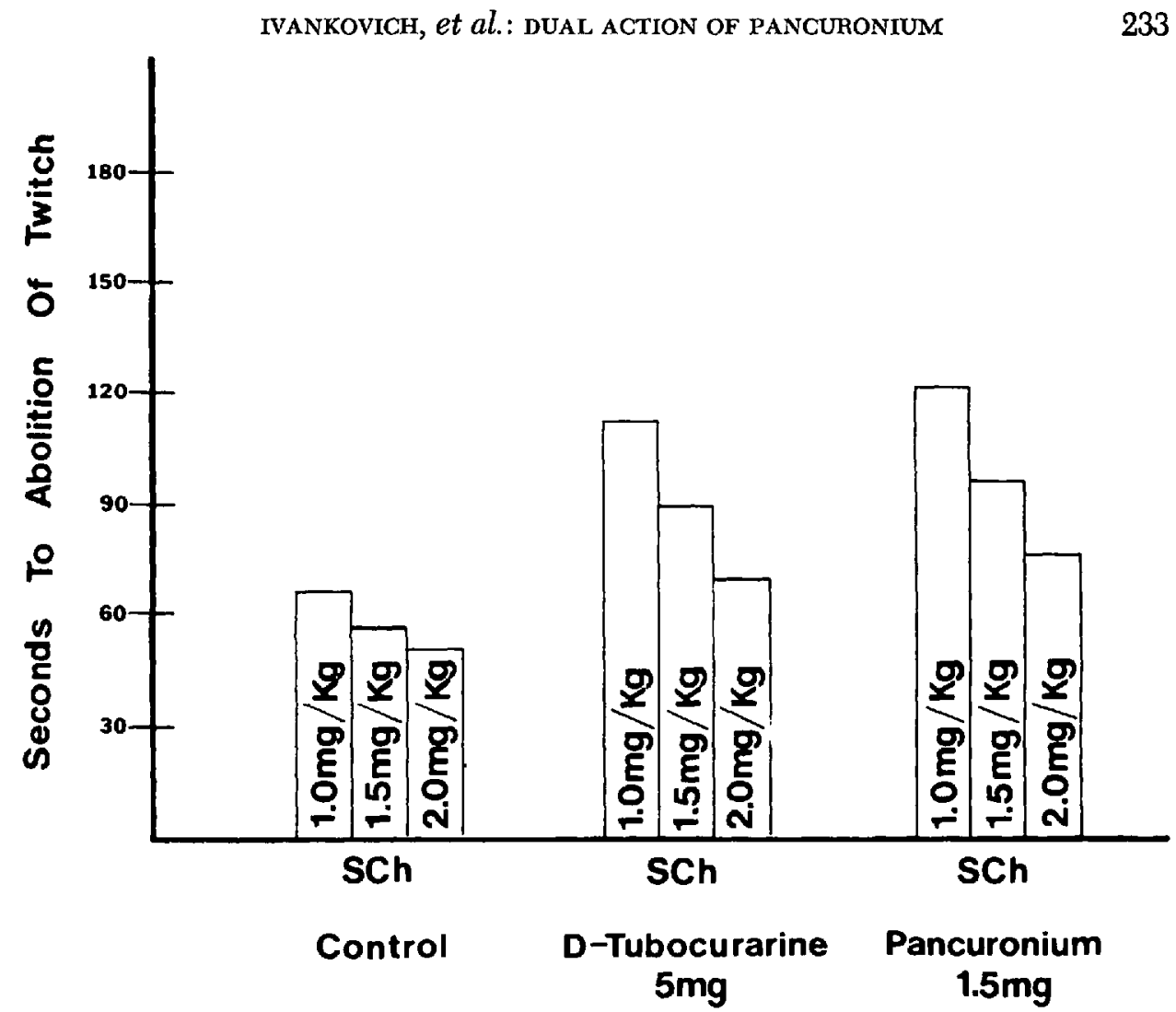

Figure 1. Average times to onset of block produced by several doses of SCh before and after pretreatment with a sub-paralyzing dose of dTC or pancuronium. Each bar represents the mean value for 15 patients.

twitch height, pancuronium $0.08 \mathrm{mg} / \mathrm{kg}$ caused complete abolition of twitch and forty minutes later when the twitch height was 35 per cent of control, post-tetanic facilitation confirmed the presence of a non-depolarizing block. Succinylcholine $2 \mathrm{mg} / \mathrm{kg}$ was again administered and initially produced a reversal of the nondepolarizing block, followed by a gradual decrease in twitch height, with the onset time to $\mathrm{SCh}$ block being 150 per cent longer than before the administration of pancuronium. Approximately 14 minutes following the injection of SCh, with twitch response either absent or recovering, tetanic stimulation resulted in a clear facilitation.

Figure 4 depicts a similar experiment in which $\mathrm{dTC}, 0.6 \mathrm{mg} / \mathrm{kg}$ produced the same initial effects as pancuronium: a delay in onset of SCh block and transitional reversal of dTC block by SCh. However, the duration of SCh block after curare was shorter than during the control period, whereas in the previous experiment this interval was prolonged after pancuronium.

The data for all experiments in Part II are summarized in Table V. The average time to abolition of twitch following control injections of SCh $2 \mathrm{mg} / \mathrm{kg}$ ranged from 51.6 to 59.1 seconds. With patients serving as their own controls, the onset time to complete block was significantly increased when identical doses of SCh were given after either dTC $0.07 \mathrm{mg} / \mathrm{kg}$ or pancuronium $0.02 \mathrm{mg} / \mathrm{kg}$. The mean 


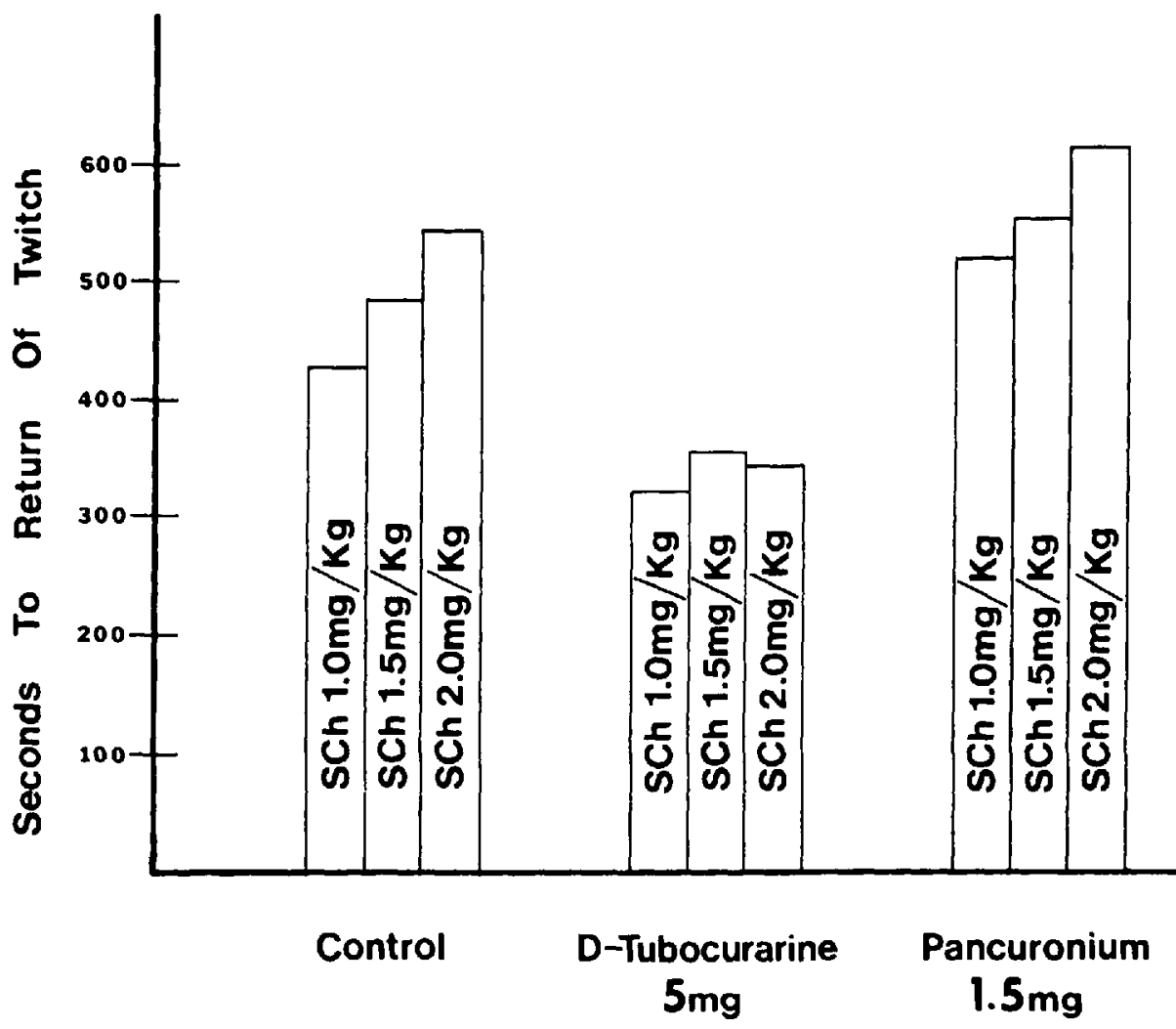

Ficune 2. Average times of duration of block produced by several doses of SCh before and after pretreatment with a sub-paralyzing dose of dTC or pancuronium. Each bar represents the mean value for 15 patients.

TABLE IV

Effect of Pancuronium and dTC On Serum Cholinesterase Activity (I.U.)*

\begin{tabular}{|c|c|c|c|}
\hline $\mathrm{N}=7$ & $\underset{\text { Mean } \pm \text { SD }}{\text { I.U. }}$ & $\mathrm{N}=8$ & $\underset{\text { Mean } \pm S D}{\text { I.U. }}$ \\
\hline Control & $7.23 \pm 1.77$ & Control & $6.76 \pm 1.15$ \\
\hline $1.5 \mathrm{mg}$ & $6.94 \pm 1.32$ & $\mathrm{dTC}, 5 \mathrm{mg}$ & $6.36 \pm 1.43$ \\
\hline
\end{tabular}

time to return of twitch significantly decreased after dTC, and significantly increased following pancuronium, thus exhibiting the same divergent pattern as in Part I. These relationships were magnified with increasing but equipotent doses ${ }^{1: 3}$ of either dTC or pancuronium. An exception was the duration of abolition of SCh twitch after dTC, which did not get progressively shorter with increasing doses of dTC.

When SCh $2 \mathrm{mg} / \mathrm{kg}$ was given following the administration of $\mathrm{dTC} 0.6 \mathrm{mg} / \mathrm{kg}$, the onset of the block was delayed by more than 100 per cent. However the dura- 


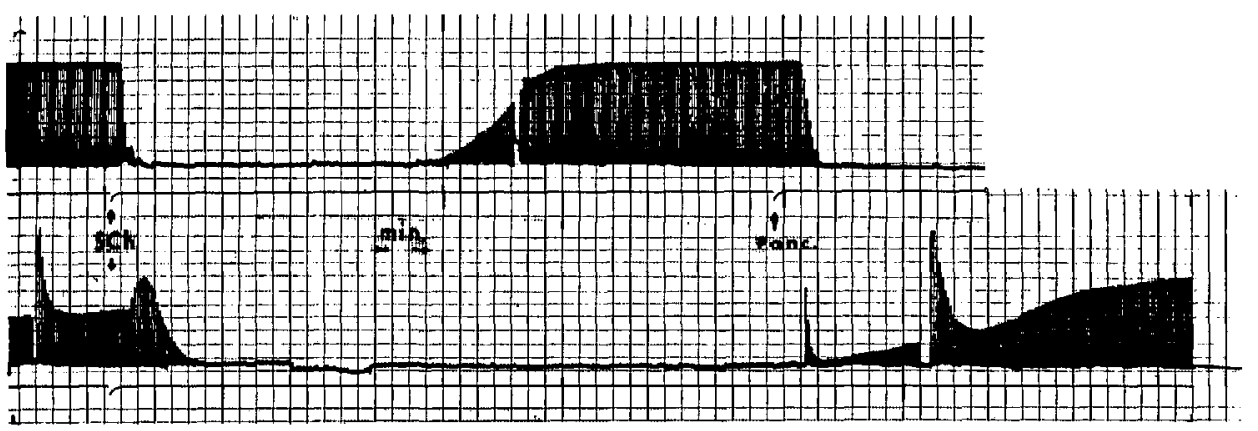

FigURE 3. Effect of a paralyzing dose of pancuronium on SCh neuromuscular block. Upper tracing: SCh $2 \mathrm{mg} / \mathrm{kg}$ produced a complete block which lasted six minutes with no post-tetanic facilitation. Lower tracing: SCh $2 \mathrm{mg} / \mathrm{kg}$ given approximately 40 minutes after pancuronium $0.08 \mathrm{mg} / \mathrm{kg}$. Note the transient reversal, delayed onset, prolonged duration of block, and posttetanic facilitation.

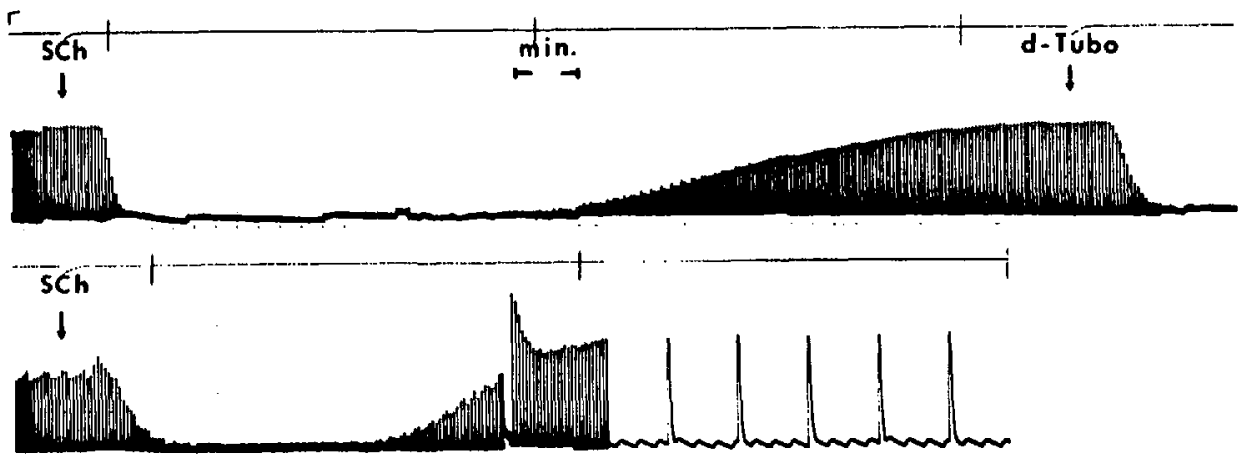

Figure 4. Effect of a paralyzing dose of dTC on SCh neuronuuscular block. Upper tracing: SCh $2 \mathrm{mg} / \mathrm{kg}$ given before dTC. Lower tracing: SCh $2 \mathrm{mg} / \mathrm{kg}$ given approximately 30 minutes after dTC- $0.6 \mathrm{mg} / \mathrm{kg}$. Note the partial reversal, delayed onset and shorter duration of block compared with control events.

tion of SCh block was not significantly different at this dose level. After the administration of pancuronium $0.08 \mathrm{mg} / \mathrm{kg}$, the onset of SCh induced block was delayed by 100 per cent compared with that produced by $\mathrm{SCh}$ alone. The average duration of SCh block in these patients was almost 17 minutes, which is twice as long as when $\mathrm{SCh}$ was given to the same patients before pancuronium. The preceding data are summarized in graphic form in Figures 5 and 6.

Average values for serum cholinesterase activity in 15 patients who received the highest dose of pancuronium in Table IV. Activity was measured prior to pancuronium $0.08 \mathrm{mg} / \mathrm{kg}$ and at five minutes and 40 minutes after its administration. During the latter interval twitch height had returned to 20 to 30 per cent of initial height. Pancuronium produced relatively small insignificant decreases in activity, with the largest individual drop still within normal limits (lower limit of normal in our laboratory is $4.0 \mathrm{I}$.U.). Thus there was no correlation between serum cholinesterase activity and the duration of SCh block after pancuronium $0.08 \mathrm{mg} / \mathrm{kg}$ in these experiments. 


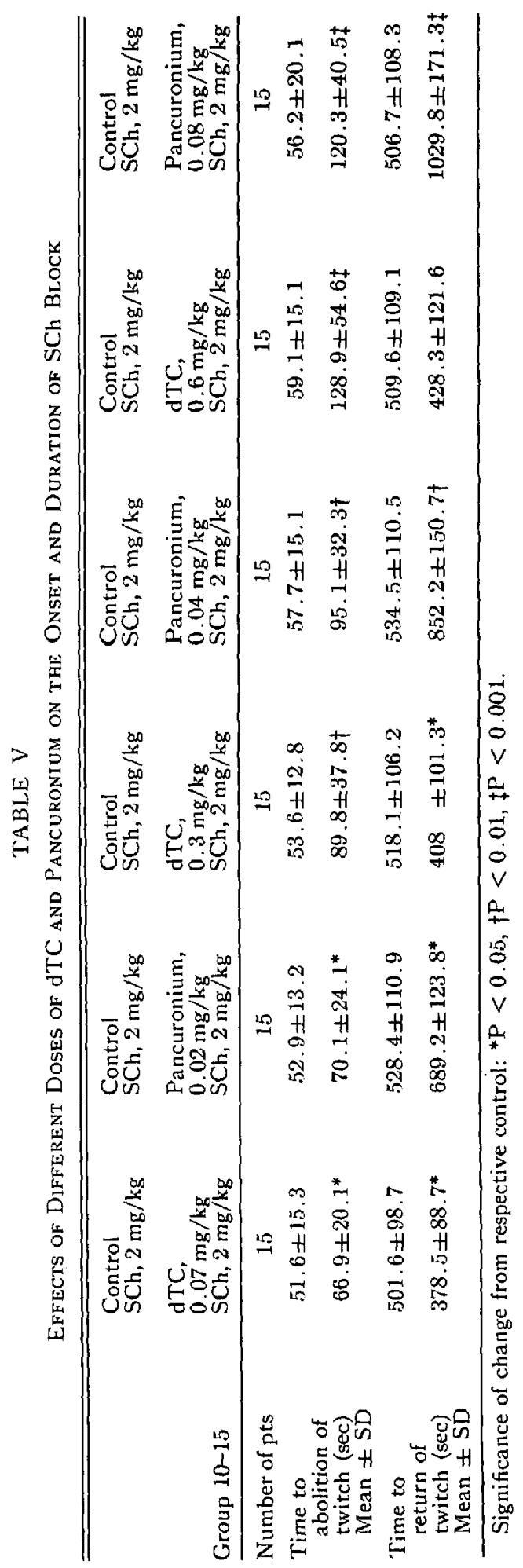




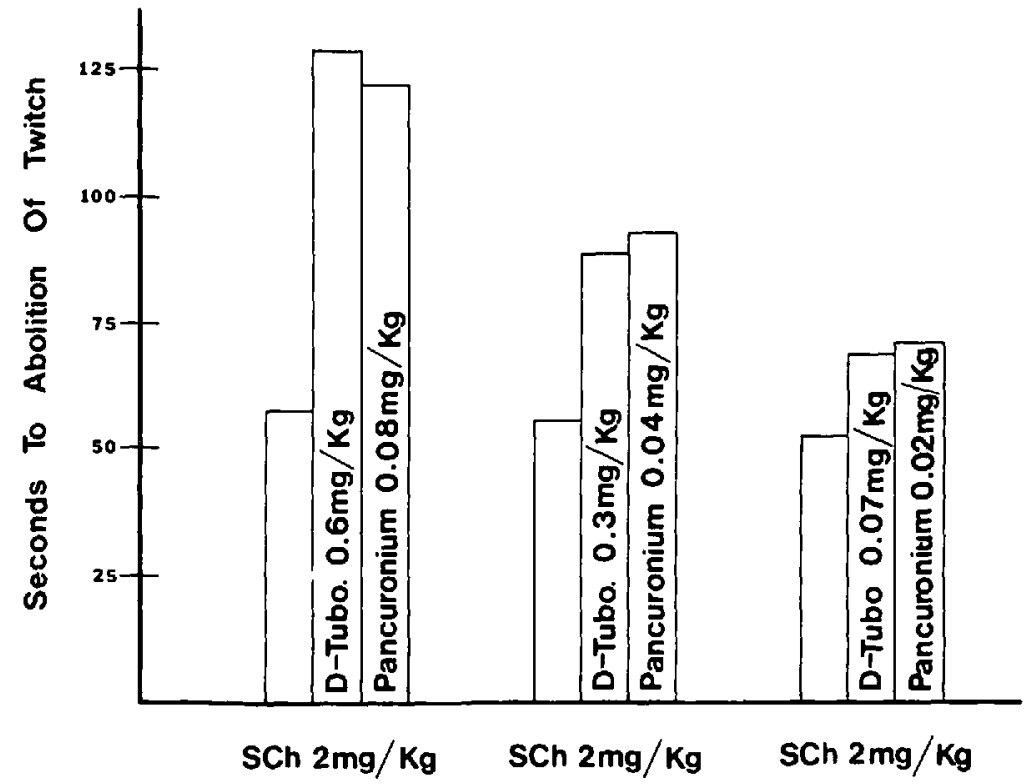

Figure 5. Average times to onset of SCh $2 \mathrm{mg} / \mathrm{kg}$ block before and after several doses of dTC or pancuronium with each patient his own control. Each dTC and pancuronium bar represents the mean value for 15 patients, while the blank bar represents the mean control value for all 30 patients in its respective triad.

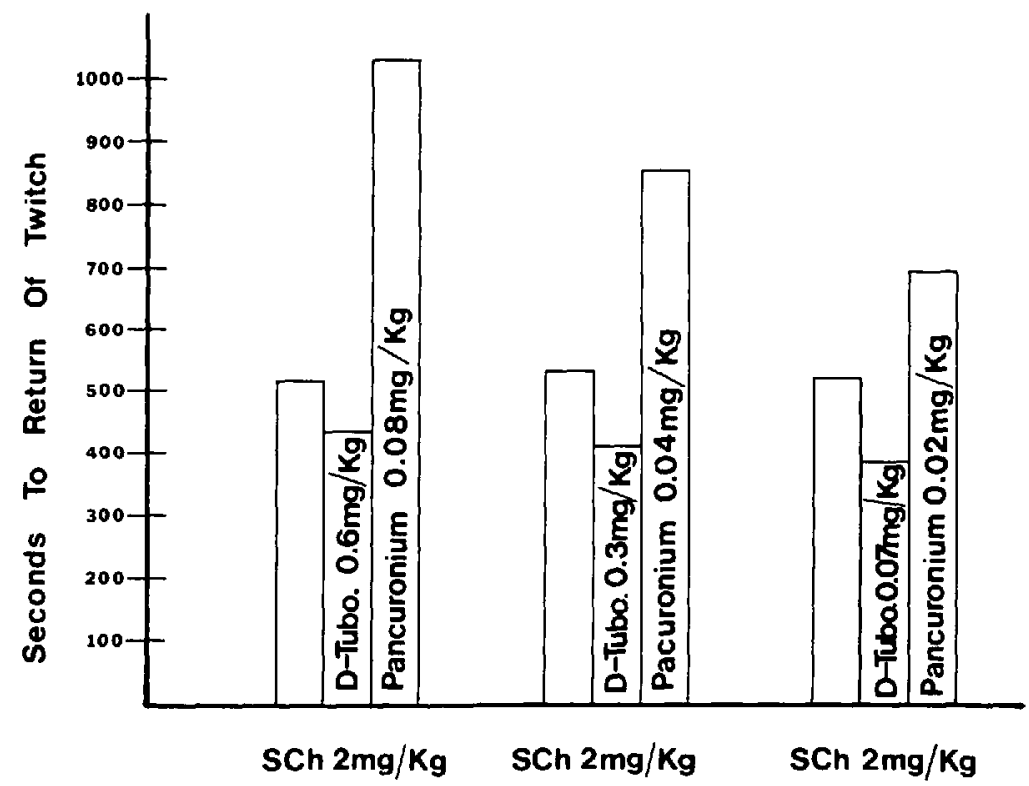

Figune 6. Average times of duration of SCh $2 \mathrm{mg} / \mathrm{kg}$ block before and after several doses of dTC or pancuronium, with each patient his own control. Mean values were calculated as indicated in Figure 5. 


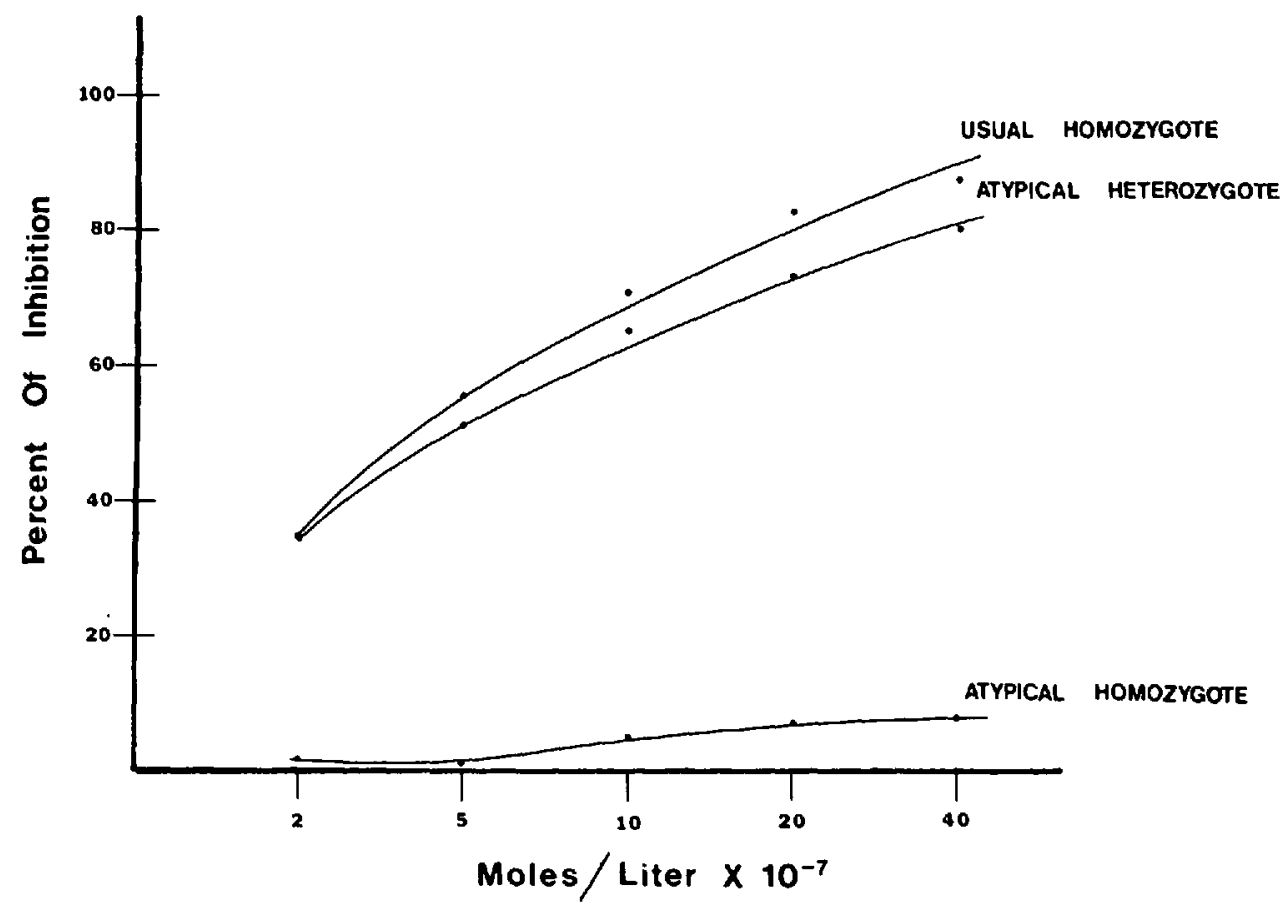

Frgure 7. Inhibition of serum cholinesterase variants in vitro by pancuronium $\left(\mathrm{I}_{50}=5 \times\right.$ $10^{-7} \mathrm{~mol} / \mathrm{l}$ ). Substrate: PTCI, $2 \mathrm{~mol} / \mathrm{litre}$.

Part III: In vitro effect of pancuronium on serum cholinesterase

The effect of pancuronium on inhibition of serum cholinesterase variants in vitro is shown in Figure 7. Pancuronium concentrations of 2 to $40 \times 10^{-7} \mathrm{~mol} / 1$ produced potent inhibition of both the usual homozygous and atypical heterozygous serum cholinesterases ranging from 34 to 88 per cent $\left(I_{50}=5 \times 10^{-7} \mathrm{~mol} / \mathrm{l}\right.$ compared with Stovner, et al. $\left.{ }^{14} 2.3 \times 10^{-7} \mathrm{~mol} / \mathrm{l}\right)$. There was only a very weak inhibition of the atypical homozygote variant. The concentrations of dibucaine necessary to produce equivalent degrees of inhibition of the usual homozygous and atypical heterozygous cholinesterase would be approximately 100 -fold higher than those used for pancuronium in this experiment. The ability of pancuronium to markedly inhibit serum cholinesterase in vitro was in striking contrast to its apparent lack of inhibition in the preceding in vivo experiments.

\section{Discussion}

The results of this study indicate that d-tubocurarine delays onset and decreases duration of succinylcholine neuromuscular block. Furthermore, the dose-response relationships exhibit a competitive type of antagonism at the neuromuscular junction. Thus, these data are in full or partial agreement with the previous work of Walts, ${ }^{6}$ Cullen, ${ }^{8}$ Miller, ${ }^{15}$ and Freund ${ }^{7}$ reporting that dTC antagonized SCh depolarizing block. The major finding of our study is that pancuronium affects $\mathrm{SCh}$ block differently than dTC when they are compared at both sub-paralyzing and 
paralyzing doses. Pancuronium produced a dual effect, first antagonizing and then potentiating the action of SCh in the same patient. Augmentation of the pancuronium depressed twitch after administration of $\mathrm{SCh}$, and the delay in the onset of SCh neuromuscular block after pretreatment with pancuronium, clearly demonstrates its antagonistic effect, while the subsequent prolongation of duration of $\mathrm{SCh}$ block is indicative of its potentiating effect.

The literature on pancuronium-SCh interactions is difficult to correlate, since many reports consist of single dose studies or lack appropriate control groups. An analysis of Cullen's data ${ }^{8}$ revealed that pancuronium ( $1 \mathrm{mg}$ ) significantly delayed the onset of paralysis by $\mathrm{SCh}(1 \mathrm{mg} / \mathrm{kg})$ but did not change the recovery time and was not as effective as dTC in preventing fasciculations. Domaoal, et al. ${ }^{10}$ using a single small dose of pancuronium $(0.5 \mathrm{mg})$, claimed greater protection against SCh $(1.5 \mathrm{mg} / \mathrm{kg}$ ) fasciculations than Cullen, but it was not possible to measure changes in onset or recovery of the SCh block since appropriate control data for these parameters were not given. On the other hand, Bennett, et al. ${ }^{9}$ found that pancuronium $1.4 \mathrm{mg}$ (equivalent to the lowest dose used in this study) was quite effective in preventing $\mathrm{SCh}(1.5 \mathrm{mg} / \mathrm{kg})$ fasciculations. They also observed that the duration of the SCh depolarizing block was prolonged after pretreatment with pancuronium. In our study, the dual effect of pancuronium in antagonizing and potentiating SCh block was observed even when pancuronium was given in subparalyzing doses as low as $1.5 \mathrm{mg}$. However, possibly due to differences in experimental design and doses, the preceding studies failed to observe both the antagonistic and potentiating effects of pancuronium on SCh block in the same patient.

The antagonism seen between $\mathrm{SCh}$ and $\mathrm{dTC}$ or pancuronium can be explained in terms of classical agonist-antagonist interaction. Succinylcholine as a depolarizing muscle relaxant is regarded as being fundamentally similar to acetylcholine at the post-synaptic junction. ${ }^{10} \mathrm{~A}$ competitive antagonism would therefore be expected when SCh is administered after a non-depolarizing muscle relaxant.

The mechanism of action of the pancuronium potentiation of duration of SCh block is more difficult to define. Inhibition of serum cholinesterase by pancuronium could explain the prolongation of $\mathrm{SCh}$ action after pretreatment with pancuronium. The potent inhibition of this enzyme by pancuronium in vitro which was observed in this study accords with the reports of other workers. ${ }^{9,14}$ A similar consensus concerning the degree of serum cholinesterase inhibition by pancuronium in vivo does not exist, due to differences in methodology, dosage regimens, and patients. Stovner, et al. ${ }^{14}$ using rigorous methodology, have reported that 45 minutes after pancuronium $0.1 \mathrm{mg} / \mathrm{kg}$ there was a 40 per cent decrease in serum cholinesterase activity, but after $0.02 \mathrm{mg} / \mathrm{kg}$ only a 10 to 15 per cent decrease. Since we observed significant prolongation of SCh block after this small dose of pancuronium (0.02 $\mathrm{mg} / \mathrm{kg}$ ) and given the wide margin of safety inherent in neuromuscular transmission, it is unlikely that serum cholinesterase inhibition is the only cause of this interaction. It is interesting that a recent study ${ }^{17}$ showed that in pregnant women when a 15 to 20 per cent decrease in serum cholinesterase activity was found, there was no prolongation in duration of SCh block. In addition, ongoing experiments in our laboratory using the isolated rat diaphragm preparation, indicate that the duration of action of $\mathrm{SCh}$ is still potentiated by pancuronium in the absence of serum 
cholinesterase. Furthermore, Bennett, et al. ${ }^{9}$ reported that dTC also inhibits serum cholinesterase in vitro; but, as shown by us and others, dTC did not potentiate the effects of SCh but antagonized them. Thus these studies do not support the hypothesis that pancuronium potentiation of SCh is solely due to the inhibition of serum cholinesterase. Another mode of action suggested by Stovner's report ${ }^{14}$ is that pancuronium inhibits human red blood cell acetylcholinesterase. There is also the possibility of a presynaptic action. ${ }^{18}$ In this regard Gergis, et al. ${ }^{19}$ using the frog gastrocnemius muscle preparation, reported that pancuronium in low concentrations $(0.003$ to $0.1 \mu \mathrm{g} / \mathrm{ml})$ released acetylcholine from nerve terminals. Both these mechanisms would increase the concentration of acetylcholine at the myoneuronal junction and thus potentiate the duration of SCh action.

In our opinion, the clinical application suggested by this study is that if a small dose of pancuronium is given prior to $\mathrm{SCh}$, then the dose of SCh should be increased to overcome the delay in onset of SCh action. We feel that a decrease in the SCh dose following pretreatment with pancuronium as recommended by Bennett and his associates, ${ }^{9}$ will result in undue delay of relaxation, which could be unsatisfactory for intubation, especially for so-called "crash" intubation. The small prolongation of $\mathrm{SCh}$ action following pretreatment with 1 to $1.5 \mathrm{mg}$ of pancuronium is not of clinical significance.

Although we do not advocate the use of SCh following large doses of non-depolarizing muscle relaxants, lack of any adverse effects of such combinations in 60 patients in our study would indicate that this practice is not dangerous, as claimed by Foldes, ${ }^{20}$ providing that neostigmine is not given before complete recovery from SCh block.

\section{SUMMARY}

The effects of pretreatment with both sub-paralyzing and paralyzing doses of pancuronium and d-tubocurarine, on the onset and duration of succinylcholineinduced neuromuscular blockade were evaluated and compared in 225 patients. D-tubocurarine antagonized both onset and duration of succinylcholine block, while pancuronium produced a dual effect, antagonizing the onset and potentiating the duration of succinylcholine block. Pretreatment with d-tubocurarine $(0.07$ $\mathrm{mg} / \mathrm{kg}, 0.3 \mathrm{mg} / \mathrm{kg}$ and $0.6 \mathrm{mg} / \mathrm{kg}$ ) increased the time to onset of succinylcholine paralysis from 28 to 118 per cent, and decreased the duration from 16 to 37 per cent. Pancuronium $(0.02 \mathrm{mg} / \mathrm{kg}, 0.04 \mathrm{mg} / \mathrm{kg}$ and $0.08 \mathrm{mg} / \mathrm{kg}$ ) also antagonized the onset of succinylcholine paralysis with increases of 32 to 114 per cent, but potentiated its duration from 30 to 103 per cent compared with succinylcholine alone in the same patients. Although pancuronium markedly inhibited serum cholinesterase in vitro $\left(\mathrm{I}_{50}=5 \times 10^{-7} \mathrm{~mol}\right)$ there was only a 10 per cent inhibition of cholinesterase in vivo after pancuronium $0.03 \mathrm{mg} / \mathrm{kg}$.

\section{RÉSUMÉ}

Les effets d'une injection préalable de d-Tubocurarine et de Pancuronium (à doses paralysantes et à doses inférieures) sur la rapidité d'action et sur la durée du 
bloc neuro-musculaire produit par la Succinylcholine, ont fait l'objet de cette étude qui a porté sur 225 patients.

La d-Tubocurarine retardait l'apparition et raccourcissait la durée d'action du bloc à la Succinylcholine. Le Pancuronium avait un double effet, à savoir : un retard à l'apparition du bloc à la Succinylcholine et une potentialisation de sa durée.

Des doses de 0.3 , de 0.6 et de $0.7 \mathrm{mg} /$ kilo en d-tubocurarine, injectées avant une dose de Succinylcholine retardaient l'apparition de paralysie à la Succinylcholine de 28 à 118 pour cent et diminuaient la durée de son effet de 16 à 37 pour cent.

Le Pancuronium à des doses de $0.02,0.04$ et $0.08 \mathrm{mg} / \mathrm{kilo}$ retardait également l'apparition de la paralysie à la Succinylcholine de 32 à 114 pour cent mais augmentait sa durée de 30 à 103 pour cent.

Bien que le Pancuronium montrait une inhibition marquée de la cholinestérase sérique, in vitro, on ne retrouvait qu'une diminution de 10 pour cent, in vivo, ceci après une dose de $0.08 \mathrm{mg} /$ kilo.

\section{REFERENCES}

1. LA Coun, D. Prevention of rise in intragastric pressure due to suxamethonium fasciculations by prior dose of d-tubocurarine. Acta Anaesth. Scand. 14:5-15 (1970).

2. Miller, R.D., WAY, W.L., \& HiCkEY, R.F. Inhibition of succinylcholine-induced increased intraocular pressure by non-depolarizing muscle relaxants. Anesthesiology 29: 123-126 (1968).

3. Morris, D.D.B. \& Dunn, C.H. Suxamethonium chloride administration and postoperative muscle pain. Brit. Med, J. I: 383-384 (1957).

4. Foldes, F.F., WNUCK, A.L., Hodges, R.J.H., et al. The mode of action of depolarizing relaxants. Anesth. Analg. 36: 23-37 (1957).

5. KATZ, R.L. \& Katz, G.J. Complications associated with the use of muscle relaxants. In Clinical Anesthesia: Muscle Relaxants 2: 125 (1966). Ed. Foldes, F.F., Davis Co., Philadelphia, $\mathrm{Pa}$.

6. Walts, L.F. \& Dillon, J.B. Clinical studies of the interaction between d-tubocurarine and succinylcholine. Anesthesiology 31:39-44 (1969).

7. Freund, F.G. \& Ruis, A.P. The need for additional succinylcholine after d-tubocurarine. Anesthesiology 36: 185-187 (1972).

8. Culles, D.J. The effect of pretreatment with nondepolarizing muscle relaxants on the neuromuscular blocking action of succinylcholine. Anesthesiology 35: 572-578 (1971).

9. Bennetr, E.J., Montcomeny, S.J., Dalal, F.Y., et al. Pancuronium and the fasciculations of succinylcholine. Anesth. Analg. 52: 892-896 (1973).

10. Domaoal, A.M., Weniger, F.C., \& Wolfson, B. "Precurarization" using pancuronium. Anesth. Analg. 54: 71-75 (1975).

11. Dietz, A.A., Rubinstein, H.M., \& Lubrano, T. Colorimetric determinations of serum cholinesterase and its genetic variants by the proprionylthiocholine-dithiobis (nitrobenzoic acid) procedure. Clin. Chem. 19: 1309-1313 (1973).

12. Feldman, S.A. Major problems in anesthesia: muscle relaxants. 1 : pp. 34-36, W.B. Saunders Co., London (1973).

13. Lund, I. \& Stovnen, J. Dose-response curves for tubocurarine, alcuronium and pancuronium. Acta Anaesth. Scand. suppl, 37: 238-242 (1970).

14. Stovneh, J., Oftedal, N., \& Holmboe, J. The inhibition of cholinesterases by pancuronium. Brit. J. Anaesth. 47: 949-954 (1975).

15. Millen, R.D. \& WAY, W.L. The interaction between succinylcholine and subparalyzing doses of d-tubocurarine and gallamine in man. Anesthesiology 35: 567-571 (1971).

16. Feldman, S.A. Major Problems in anestheisa: muscle relaxants. 1: pp. 32-33, W.B. Saunders Co., London (1973).

17. Blitt , C.D., Petry, W.C., Albentennst, E., et al. Correlation of plasma cholinesterase activity and duration of action of succinylcholine during pregnancy. Presented at the 50th International Anesthesia Research Society Meeting, March 15, Phoenix, Arizona (1976). 
18. Galindo, A. Curare and pancuronium compared: effects on previously undepressed mammalian myoneural junctions. Science 178: 753-755 ( 1972 ).

19. Gergis, S.D., Dretchen, K.L., Sokoll, M.D., et al. Effect of pancuronium bromide on acetylcholine release. Proc. Soc. Exp. Biol. Med. 139: 74-76 (1972).

20. Foldes, F.F. The choice and mode of administration of relaxants. In Clinical Anesthesia: Muscle Relaxants. 2: p. 21, Ed. Foldes, F.F., Davis Co., Philadelphia, Pa. (1966). 